\title{
Faktor Pengetahuan dan Perilaku Petani Penyemprot yang Berhubungan dengan Kadar Serum Cholinesterase di Kabupaten Brebes
}

\author{
Devi Ayu Susilowati*, Suhartono**, Bagoes Widjanarko ${ }^{* *}$ \\ "Dinas Kesehatan Kota Semarang, ${ }^{* *}$ Fakultas Kesehatan Masyarakat Undip
}

\begin{abstract}
Background: Spray farmers are is one of the population at risk for pesticide poisoning. To determine the presence of pesticide exposure and risk assessment of pesticide poisoning is by measuring serum ChE levels. Based on the data results of ChE examination by Brebes District Health Office found 5.5\% mild poisoning in Dukuhlo Village. This study aims to analyze the relationship between knowledge, attitude and behavior of the use of pesticides with serum cholinestearse levels in spraying farmers.

Method: This research use cross sectional design. Involved 88 farmer sprayers in Dukuhlo Village. The research variables were age, nutritional status, knowledge, attitude, completeness of PPE, smoking when spraying, spraying on wind direction, cleaning sweat by hand or cloth, reentering agriculture area, spraying time, frekuesni spraying, pesticide storage method, and Last time to spray. Data were analyzed by multivariate analysis.

Results: Factors shown to be associated with serum ChE levels were knowledge of pesticides ( $\mathrm{p}$ $=0.005$; OR: 12,$369 ; 95 \% \mathrm{CI}=2,1-71,5)$ and smoking when spraying $(\mathrm{p}=0.005$; OR: 9,641; $95 \% \mathrm{CI}=2.0-46.1)$. Factors not shown to be associated with se rum ChE levels are age, nutritional status, attitude, completeness of APD application, spraying on the wind direction, sweating with hands or cloth, reentering agriculture, spraying, fracturing spraying, Pesticides, and last time to spray

Conclusion: Factors associated with serum ChE levels are knowledge of pesticides and smoking when spraying. Health counseling is needed to increase knowledge about pesticides and the dangers of smoking while spraying.
\end{abstract}

Keywords : Related factors; spray farmers; serum ChE levels

*Penulis korespondensi : deviayususilowati@gmail.com 


\section{Pendahuluan}

Pestisida adalah zat atau campuran zat kimia atau biologi yang digunakan untuk mengontrol hama dan hewan-hewan yang menyebabkan kerusakan atau mengganggu produksi serta mengontrol pertumbuhan tanaman. Efek kesehatan yang ditimbulkan dari paparan pestisida yaitu sebagai zat mutagenik, karsinogenik, pengganggu endokrin, pengganggu sistem reproduksi dan zat neurotoksik. ${ }^{1,2}$ Pestisida bisa masuk ke dalam tubuh melalui digesti, inhalasi dan melalui permukaan kulit yang tidak terlindungi. ${ }^{3}$ Adanya paparan pestisida di dalam tubuh dapat diketahui dengan memeriksa aktifitas enzim cholinesterase. Golongan organofosfat bekerja dengan cara menghambat aktivitas enzim cholinesterase sehingga asetilkholin tidak dapat terhidrolisa dan jumlahnya berlebih yang mengakibatkan rangsangan terus-menerus pada saraf muskarinik dan nikotitinik. ${ }^{4}$

Salah satu populasi berisiko untuk mengalami dampak negatif jangka panjang dari penggunaan pestisida adalah petani penyemprot, hal ini berkaitan dengan keterlibatan mereka dalam kegiatan pertanian seperti mencampur pestisida, menyemprot, mencuci peralatan sampai memanen. Dampak merugikan penggunaan pestisida diantaranya adalah kesulitan bernafas, sakit kepala, efek neurologis atau psikologis, iritasi kulit dan selaput lendir. Manifestasi dari efek tersebut tergantung pada jenis pestisida dan pada tingkat dan durasi paparan.

Negara berkembang hanya menggunakan $25 \%$ dari pestisida yang diproduksi di seluruh dunia, tetapi masyarakat di negera berkembang tersebut mengalami kematian sebesar 99\% hal ini dikarenakan penggunaan pestisida di negara berkembang yang lebih intens, tidak aman, sistem peraturan, kesehatan dan pendidikan yang lebih lemah dibandingkan dengan negara maju. ${ }^{6}$

D i I n d o n e s i a, perse n t a s e penggunaan/penyimpanan pestisida oleh Rumah Tangga (RT) di dalam rumah sekitar $20 \%$ hal ini menunjukkan masih ada risiko paparan pestisida tidak hanya di area persawahan tetapi juga di dalam rumah, sedangkan di Provinsi Jawa Tengah, proporsi rumah tangga dalam penggunaan pestisida sebesar $17,1 \%$ sedangkan proporsi penduduk umur $\geq 10$ tahun yang berperilaku benar dalam cuci tangan setelah menggunakan pestisida tahun 2013 masing-masing 49,5\%.

Kabupaten Brebes merupakan daerah pertanian bawang merah terbesar di Provinsi Jawa Tengah dengan penggunaan pestisida yang tinggi pula. Berdasarkan pemeriksaan cholinesterase yang dilakukan oleh Dinas Kesehatan Kabupaten Brebes persentase keracunan selama tahun 2014-2016 sangatlah fluktuatif yaitu 5,24\%, 0,76\%, $7,53 \%$ dan $1,44 \%$, kenaikan tersebut tidak sepenuhnya bisa dijadikan indikator yang buruk mengingat jumlah sampel yang diperiksa, tempat dan waktu pemeriksaan selalu berubah. ${ }^{9}$

Desa Dukuhlo merupakan salah satu desa di Kecamatan Bulakamba yang mengandalkan bawang merah sebagai komoditas utamanya dengan luas tanam 84 Hektar. Hasil pemeriksaan cholinesterase di Desa Dukohlo oleh DKK Kabupaten Brebes pada tahun 2013 ditemukan keracunan ringan sebesar $5,5 \%{ }^{10-11}$

Studi di negara-negara berkembang melaporkan rendahnya tingkat pengetahuan dan buruknya praktek petani tentang pembuangan wadah sisa pestisida, selain itu juga petani tidak menggunakan APD pada saat melakukan pekerjaan, praktik penyimpanan pestisida yang tidak aman di rumah, dan pengetahuan tentang label keselamatan pestisida yang masih rendah. ${ }^{11-12}$ Dalam penelitian Boonkawee et al menyebutkan bahwa petani yangselalu menggunakan pelindung dirimemiliki kadar serum cholinesterase lebih baik dibandingkan dengan yang tidak menggunakan pelindung diri $(p=0,001){ }^{13}$ Dalam penelitian lainnya menemukan bahwa petani yang melakukan kontak terakhir $\leq 2$ minggu mempunyai risiko sebesar 5,8 kali untuk mengalami keracunan dibandingkan dengan petani yang melakukan kontak terakhir $>2$ minggu yang lalu. ${ }^{14}$

Berdasarkan penjelasan dan uraian tersebut, peneliti tertarik untuk meneliti lebih lanjut mengenai faktor pengetahuan dan 
perilaku yang berhubungan dengan kadar serum cholinesterase pada petani penyemprot di Desa Dukuhlo Kecamatan Bulakamba Kabupaten Brebes yang bertujuan membuktikan faktor pengetahuan, merokok ketika menyemprot dan kelengkapan APD yang digunakan berhubungan dengan kadar serum cholinesterase pada petani penyemprot.

\section{Metode}

Jenis penelitian observasional analitik dengan metode cross sectional. Penentuan jumlah sampel dalam penelitian ini menggunakan rumus uji hipotesis untuk populasi tunggal dengan teknik sampling adalah purposive sampling. Dari hasil perhitungan tersebut diperoleh besar sampel minimum sebanyak 72 sampel, tetapi dalam pelaksanaanya terdapat 88 sampel dikarenakan tingginya antusisas petani penyemprot untuk memeriksakan diri.

Variabel dependent penelitian ini yaitu kadar serum cholinesterase yang didapatkan dari hasil pemeriksaan laboratorium oleh Laboratorium Cito Tegal. Variabel independen yang diteliti adalah pengetahuan tentang pestisida, merokok ketika menyemprot dan kelengkapan APD yang digunakan ketika menyemprot. Pengumpulan data primer dilakukan dengan wawancara menggunakan kuesioner yang sebelumnya sampel telah diberikan informed concent. Hasil penelitian dianalisis secara bivariat menggunakan yaitu chi square $\left(\mathrm{x}^{2}\right)$ dengan tingkat kemaknaan $\mathrm{p}<0,05$, confidence interval (CI) $95 \%$ dan analisis multivariat dengan multipel regresi logistik.

\section{Hasil}

Penelitian dilakukan di Desa Dukuhlo Kecamatan Bulakamba Kabupaten Brebes Provinsi Jawa Tengah pada 88 petani penyemprot. Sebagian besar petani penyemprot berusia $\geq 45$ tahun $(72,2 \%)$, berpendidikan SD/Sederajat $(51,1 \%)$, waktu terakhir menyemprot $0-2$ hari yang lalu $(38,6 \%)$, jenis tanaman yang disempeor 3 bulan terakhir adalah padi $(72,7)$ dan jenis pestisida yang banyak digunakan adalah merk "Dusban" (37,5\%). Berdasarkan tingkat pengetahuan tentang pestisida, diketahui bahwa sebagian besar petani penyemprot mempunyai tingkat pengetahuan tentang pestisida yang baik (58\%). Dilihat dari perilaku subjek ketika menyemprot, diketahui bahwa sebagian besar responden kelengkapan APD ketika menyemprot adalah baik $(72,7 \%)$ dan tidak merokok ketika menyemprot (81,8\%). Hasil pemeriksaan serum cholinesterase diperoleh petani penyemprot yang memiliki kadar serum cholinesterase yang rendah $(<5,320$ U/L) sebesar 13,6\% (Tabel 1).

Hasil analisis bivariat dengan uji chisquare diketahui bahwa faktor yang berhubungan dengan kadar serum cholinesterase pada petani penyemprot adalah merokok ketika menyemprot $(p=0,008 ; R P 4,5 ; 95 \%$ CI 1,6-12,1) dan pengetahuan tentang pestisida $(\mathrm{p}=0,005$; RP 6,9; 95\% CI 1,6-29,6) (Tabel 2). Variabel dengan nilai $\mathrm{p}<0,25$ dimasukkan dalam analisis multivariat meliputi merokok ketika menyemprot dan pengetahuan tentang pestisida. Hasil analisis multivariat regresi logistik diketahui bahwa faktor yang yang berhubungan dengan kadar serum cholinesterase pada petani penyemprot adalah merokok ketika menyemprot $(p=0,005 ; O R=12,369 ; 95 \% \mathrm{CI}=2,1-71,5)$ dan pengetahuan tentang pestisida $(\mathrm{p}=0,005 ; \mathrm{OR}=9,641 ; 95 \% \mathrm{CI}=2,0-46,1)$ (Tabel 3).

\section{Pembahasan}

Proporsi petani penyemprot dengan kadar serum cholinesterase rendah lebih besar pada kelompok petani yang merokok ketika menyemprot $(37,5 \%)$ dibandingkan tidak merokok ketika menyemprot $(8,3 \%)$. Hasil analisis multivariat menyatakan bahwa petani penyemprot yang merokok ketika menyemprot mempunyai risiko 12,369 lebih besar mempunyai kadar serum cholinesterase yang rendah dibandingkan petani penyemprot yang tidak merokok ketika menyemprot $(\mathrm{p}=0,005 ; \mathrm{OR}=12,369$; 95\% CI=2,1-71,5). Pada asap rokok, terkandung berbagai senyawa, diantaranya tar dan nikotin yang ternyata mempunyai 
pengaruh terhadap cholinesterase. ${ }^{15}$ Penelitian ini sejalan dengan penelitian Ruhendi yang menunjukkan hubungan bermakna dengan aktivitas cholinesterase darah adalah merokok saat menyemprot $(p=0,0001, O R=6,582,95 \%$ CI $=2,881$ 15,037). ${ }^{16}$ Dalam penelitian lainnya juga menunjukkan bahwa merokok yang lebih sedikit merupakan faktor protektif dalam risiko keterpaparan pestisida ke dalam tubuh (PD -0.20; CI-0.34, -0.07). ${ }^{17}$ Hasil analisis multivariat dalam penelitian Kachaiyaphum et al menunjukkan bahwa terdapat hubungan antara kebiasaan penggunaan pestisida yang sedang atau buruk dengan kadar SchE yang abnormal dibandingkan dengan kebiasaan yang baik, kebiasaan dalam hal ini adalah merokok ketika menyiapkan dan mengaplikasikan pestisida. ${ }^{18}$

Berdasarkan hasil penelitian di lapangan diperoleh informasi bahwa alasan petani penyemprot yang merokok ketika menyemprot yaitu mereka tidak merasakan efek kesehatan yang negatif, mereka merasa sudah kebal dan kuat terhadap paparan asap rokok walaupun pada saat menyemprot. Setelah menyemprot mereka beristirahat untuk makan dan minum kemudian merokok kembali.

Proporsi petani penyemprot dengan kadar serum cholinesterase rendah lebih besar pada kelompok pengetahuan tentang pestisida yang kurang $(27 \%)$ dibandingkan pengetahuan baik $(3,9 \%)$. Petani penyemprot yang pengetahuan tentang pestisida yang rendah mempunyai risiko 9,641 kali lebih besar mempunyai kadar serum cholinesterase yang rendah dibandingkan petani penyemprot yang memiliki pengetahuan tentang pestisida yang baik $(\mathrm{p}=0,005 ; \mathrm{OR}=9,641 ; 95 \%$ $\mathrm{CI}=2,0-46,1)$. Hasil penelitian ini sejalan dengan penelitian yang dilakukan oleh Budiawan yang menghasilkan hubungan yang signfikan antara tingkat pengetahuan dengan cholinesterase petani bawang merah di Ngurensiti Pati $(p=0,002) .{ }^{19}$

Pengetahuan adalah hasil dari tahu dan terjadi setelah melakukan penginderaan terhadap objek tertentu. Sebagian besar pengetahuan manusia diperoleh melalui mata dan telinga. Pengetahuan merupakan hal yang sangat penting dalam membentuk tindakan seseorang. Teori Cognitive Consistency bahwa terdapat hubungan konsisten dalam diri seseorang yaitupengetahuan, sikap dan perilaku. Perilaku dapat diubah dengan cara merubah pengetahuan dan sikap. Proses pendidikan akan berpengaruh pada perubahan pengetahuan dan merubah sikap seseorang yang akan menghasilkan perubahan pada perilaku. Pengetahuan dapat diperoleh seseorang melalui berbagai macam alat bantu seperti media cetak, media elektronik (televisi, radio, video, slide) dan media papan yang berisi pesan kesehatan. ${ }^{20}$ Berdasarkan hasil penelitian di lapangan diperoleh informasi bahwa belum ada penyuluhan tentang bahaya pestisida bagi petani penyemprot.

Peningkatan pengetahuan bagi petani penyemprot tentang informasi umum tentang pestisida, faktor risiko keracunan pestisida sampai dengan pencegahan keracunan perlu dilakukan untuk menurunkan kejadian rendahnya kadar serum cholinesterase petani penyemprot. Pemeriksaan cholinesterase secara rutin oleh Dinas Kesehatan Kabupaten Brebes juga perlu dilakukan untuk memonitoring kadar cholinesterase khususnya petani penyemprot yang intensitas penggunaan pestisidanya sangat tinggi.

\section{Kesimpulan}

Merokok ketika menyemprot dan pengetahuan tentang pestisida yang rendah merupakan faktor yang berhubungan dengan kadar serum cholinesterase pada petani penyemprot di Desa Dukuhlo Kecamatan Bulakamba Kabupaten Brebes. Petani penyemprot yang merokok ketika menyemprot mempunyai risiko 12,369 lebih besar mempunyai kadar serum cholinesterase yang rendah dibandingkan petani penyemprot yang tidak merokok ketika menyemprot dan pengetahuan tentang pestisida yang rendah mempunyai risiko 9,641 kali lebih besar mempunyai kadar serum cholinesterase yang rendah dibandingkan petani penyemprot yang memiliki pengetahuan tentang pestisida yang baik. 


\section{Ucapan Terimakasih}

Terimakasih kepada Laboratorium Cito Kota Tegal yang telah memberikan ijin dalam pengumpulan data serta berbagai pihak yang telah mendukung dalam penelitian ini.

\section{Daftar Pustaka}

1. FAO. 2016. The International Code of Conduct on Pesticide Management. Rome: FAO.pp.6

2. Sanborn M, Kerr KJ, Sanin LH, Cole DC, Bassil KL, Vakil C. 2007. Noncancer Health Effects of Pesticides Sys tematic Review and Implications for Family Doctors. Can Fam Physician. pp.53.

3. Ogg, C.L., et al. 2012. Managing The Risk of Pesticide Poisoning and Understanding The Sign and Symproms. Extenstion. University Nebraska Lincoln.

4. Wudiyanto R. 2008. Petunjuk Penggunaan Pestisida. Jakarta: Swadaya

5. Bretveld RW, Thomas CMG, Scheepers Zielhuis, Roeleveld N. 2017. Pesticide Exposure: The Hormonal Function of The Female Reproductive System Disrupted?Reproductive System Disrupted? pp.4

6. WHO. 2008. Pesticides-Children's Health and The Environment.

7. Kemenkes RI. 2013. Riset Kesehatan Dasar.

8. Kementerian Kesehatan RI. 2013. Riskesdas dalam Angka Provinsi Jawa Tengah. Lembaga Penerbitan Badan Penelitian dan Pengembangan.

9. DKK Kabupaten Brebes . 2014. Profil Kesehatan Kabupaten Brebes 2014.

10. BPS. 2016. Statistik Pertanian Hortikultura Jawa Tengah 2012-2014.

11. Ibitayo O O. 2006. Egyptian Farmers Attitudes and Behaviors Regarding Agricultural Pesticides:Implications for Pesticide Risk Communication. Risk Anal;26(4).

12. Ajayi OC, Akinnifesi FK, Programme SA, Box PO. 2007. Farmers'understan- ding of Pesticide Safety Labels and Field Spraying Practices: A Case Study of Cotton Farmers in Northern Côte d Ivoire. Sci Res Essays; 2(June). pp. 204-210.

13. Boonyakawee,P., Taneepanichskul, S., Chapman, R.S. 2013. Knowledge, Atti tude and Practice in Insecticide Use, Serum Cholinesterase Levels and Symptom Prevalence among Shogun Orange Farmers in Khao-Phanom District,Krabi Province Thailand. J Health Res; 27(3).pp.196-191.

14. Suryamah. 2007. Analisis Pemajanan Pestisida dengan Tingkat Keracunan Pestisida pada Petani Perkebunan di Kabupaten Bandung Tahun 2006.

15. Rustia, H.N, Wispriyono B, Susanna D, Luthfiah FN, et al. 2010. Lama Pajanan Organofosfat Terhadap Penurunan Aktivitas Enzim Kolinerase Dalam Darah Petani Sayuran. Makara Kesehat;14(2). pp.95-101.

16. Ruhendi, D. 2007. Faktor Determinan Aktivitas Kholinesterase Darah Petani Holtikultura di Kabupaten Majalengka. Jurnal Kesehatan Masyarakat Nasional.

17. Issa, Y., Sham'a, F.A., Nijem, K., Bjertness, E., Kristensen, P. 2010. Pesticide Use and Opportuniies of Exposure among Farmers and Their Families:Cross-Sectional Studies 1998-2006 From Hebron Governorate ,Occupied Palestinian Territory; 9 18. (63)

Kachaiyaphum, Ujirat, D., Siri. D., Suwannapong, N. 2010. Serum Cholinesterase Levels of Thai Chili-Farma Workers Exposed to Chemical Pesticides: Prevalence Estimates and Associated Factors. 2010.pp.52.

19. Budiawan AR. 2014. Faktor Risiko yang Berhubungan dengan Cholinesterase Pada Petani Bawang Merah di Ngurensiti Pati. Unnes J Public Health ;3(1).pp.1-11.

20. Long, R. 2013. Introductory Sociology, Sosial Class (Stratification) http://dmc 122011.delmar.edu/socsci/rl ong/intro/ class.htm. 